\title{
Reciprocal Reinforcement of Entangled Narrations on Outer and Inner European Borders. Romani People, Nation States and Europe
}

\author{
Iulia-Karin Patrut (iulia-karin.patrut@uni-flensburg.de) \\ Europa-Universität Flensburg, Germany
}

\begin{abstract}
Narrations about "Europe" always contain assumptions about the cultural and social homogeneity and heterogeneity of the groups that are supposed to be included in or excluded from the imaginary European community. Contemporary literary texts have developed narrative strategies that can negotiate criteria and procedures establishing the outer and inner borders of communities. They also construct sometimes critical, sometimes affirmative correlations between Europe's outer border and imaginary thresholds and depict certain groups, such as the Roma, as 'non-European'. Some of these literary and journalistic narrations construct an alleged correspondence between the (imagined) characteristics of Roma people and 'non-Europeans', thereby reinforcing both the coherence of European outer borders and the cohesion of the internal homogeneity of 'Europeans', who are defined as non-Romani. These narrations obviously have a real impact on practices of inclusion/exclusion of people, as this article seeks to show. Exploring the possibilities of literary texts to create second-order-observing positions and to generate heteronomy and counter narratives, this study focusses on the works of Herta Müller and especially her story 'The Big Black Axis' and asks whether they succeed in developing counter-narratives. It also discusses the potential of these texts to change patterns of inclusion/exclusion and considers issues of self-representation and politics of recognition.
\end{abstract}

Keywords: Liminal figures, border narrations, Herta Müller, "Die große schwarze Achse", Romanies

\section{Introduction: Border narrations and liminality}

Poststructuralist narratology persists in viewing border-crossing as a pre-condition for the occurrence of narration. Thus, Jury Mikhailovich Lotman stated as early as 1972 that any literary text only makes sense because it first separates two disjunct spaces and erects a border that cannot be crossed by definition; the text only merits narration because the characters, the narrators voice, and the reader's gaze finally do cross this border or threshold (Lotman 1972, 327). This idea became one of the cornerstones of cultural semiotics as well as advanced poststructuralist literary theories that negate the disjunct spaces and focus only on the deconstructive and paradoxical moment when the threshold is crossed (Robinson 2007). Trespassing rules and transgressing subject positions are firmly established scenarios in literary texts, and so is the crossing of political (state) borders. The 
conceptualizations of imaginary and of political border-crossings are interdependent. Geographical border regions are often culturally under- or over-determined (as are situations of in-between imaginary borders in literary texts) and thus often serve as settings for reflection on border regimes as well as utopias, dystopias and propaganda (Hormuth 2013). Undoubtedly, literature has significantly contributed to the positive emotional and cognitive charge of imaginary border-crossing. Examples range from ancient mythical narrations like Orpheus' descent into Hades or Gilgamesh's experience in the liminal space between wake and sleep, between the living and the dead, to modern novels and stories such as Franz Kafka's "A Report for an Academy", which takes place on the margins of humanity by keeping readers in the dark regarding the condition of the narrator, who might be a trained ape pretending to be a human, or a human who has been stigmatized and defamed as monkey (one of the strategies of antisemitic and also racist anti-African discourse).

In this example, the critical potential of narrations that challenge the limits of humanity, of life, of species, of cultures or any kind of groups becomes obvious. In Kafka's story, narrations on the margins of humanity (imagined borders in biology and anthropology) get overlaid by narrations on the margins of continents (geographical and political borders), and narrations between Christians and Jews (religious and cultural borders). Readers only read the narrator's voice, affirming that he was formerly an ape and is now urged by the Academy of Sciences to draft a report explaining how he managed to traverse the limit between apehood and humankind. In his scientific report - which is the only content of the narrative - he explains that he was captured on the Gold Coast by the members of a zoological expedition from Hagenbeck, shot by firearms, and subsequently shipped to Europe. Undoubtedly, the story refers to the 'human zoos', where persons from the colonized Southern hemisphere were exhibited as curiosities and forced to simulate putative traditional occupations.

"A Report for an Academy" draws attention to the correlations between borders constructed in the epistemic patterns of culture and society (in the imaginary order of things) and the state frontiers that separate colonizing from colonized countries in Europe and in Africa (Kpao Saré 2015). In general, but also in every concrete case, political frontiers aim to obtain their legitimacy from the ideas of allegedly vindicated differences, scientifically proven distinctions, and geographical evidence.

Literary narrations have the potential to disclose these interdependencies and thus to question the ideologies that legitimize the frontiers and the border regime. They can provide this by renouncing immediate referencing: because they do not claim to be 'true' rather an experiment in thought and emotion, literary narrations have a much higher degree of freedom when it comes to reflecting preconditions, implications and consequences of imaginary and political border demarcations. They also can negotiate the violence involved in dichotomies accompanied by distinctions and power asymmetries, and can thus affect societal reality from a second observation level, when readers relate the results of the literary text's experiments on cognition and emotion to their own knowledge and experience with political borders. Of course, the opposite case-literary texts that sustai and legitimize antisemitic, racist or other differentiating propaganda in favour of borders and frontiers-is not at all uncommon in literary history; but recently scholarly attention (e.g. that of Uerlings 2006, Mecklenburg 2008) has increased regarding texts that, over the long run, have substantially unmasked and questioned imagined and concrete world architectures, their implicit differentiations and discriminations, and their structural and physical violence effects.

Thus, many literary texts serve as archives of the past deliberations of 'Europe' and 'Europeanization', understood as ongoing processes of multilayered border negotiations. Internal and external, imaginary and political, geographical and cultural frontiers of and within 
Europe have been continuously challenged in the field of literary narration - since the very emergence of the idea of the continent.

More recently, historical narrations of liminality are of particular importance for their ability to reveal the plasticity and permeability of frontiers. At the same time, they demonstrate that the condition of liminality is ambivalent in that it is associated both with a lack of power and with a position of power regarding future transformations of culture and society. Reflection and transformation are more likely to emerge at the margins, or 'inbetween', renouncing the advantages of centrality offered by established structures; in liminal spaces, alternative possibilities, hybridization - which always means innovation and experiences of similarity instead of radical difference occur. As a consequence liminality, marginalized persons or groups, and the geographical space nearby political frontiers have been appealing topics since the very beginning of oral and written narration and literature.

This article explores the depiction of Romani in dissident literature, more precisely of Herta Müller's depiction of so -called 'Gypsies' in her text "The Great Black Axis". The plot is located in a European border region, near the borders of Hungary, Romania and Serbia, in the multilingual and multireligious region called Banat, which formerly was a part of the Austro-Hungarian monarchy.

It is necessary to use the term 'Gypsies' instead of 'Romani,' because the text deals with the stigmatization and marginalization linked mainly to this designation, a discoursive construction not primarily linked to ethnicity, which emerged from administrative, police enforcement and law practices designed to exclude the persons referred to by this stigmatizing term (Bogdal 2011). This external designation did not give those to whom it referred the opportunity to take a stand on the matter. Nevertheless, I will argue that Müller resignifies the stigma in order to challenge European inner and outer frontiers and to develop forms of literary resistance against totalitarianism and censorship.

Dissident writings from the Eastern side of the 'iron curtain' counteracting state and frontier propaganda with aesthetic and poetic means offer telling examples of literary opposition against stigmatizing discourses and practices of exclusion. Their potential to challenge imaginary as well as political border regimes is revealed by the attention and repression to which these texts and their authors were exposed. Censors carefully annotated the confiscated manuscripts, such as the texts written by Müller, a German speaking writer in socialist Romania who later won the Nobel prize (Petrescu 2014), and sought interpret them to ensure that they had capured every potentially subversive implication. In general, many authors who wrote in German were suspected by the Securitate of being crypto fascists (Cseika/Sienerth 2015). This young generation of writers, which was rather indebted to Bertolt Becht, to the post-avant-garde, and to European literature, tried to break with German national patterns and with self-assertions related to the region.

When Herta Müller depicts 'Gypsy' figures in her texts, as she does in "The Great Black Axis" - a story to be discussed in detail in this paper - she deals with marginalized persons who are in a situation of liminality (Patrut 2013). Due to the discursive positioning of Romani on the threshold of Romanian society (?), discourses of societal self-depiction that rely on their exclusion have the power to define this group in a way that is 'productive' for the self-proclaimed (?) non-Gypsy-society (Patrut 2013 and 2014). Since the $17^{\text {th }}$-century literary, however, strategies of narration have been developed to unveil the economic and political aspects of the exclusion that strikes those who are being instrumentalized as embodiments of the threshold of the collective 'self' in most European societies (Patrut 2014). Some researchers have pointed out that Herta Müller's texts contain marginalized characters and fragile subjects, who typically tend to unmask and to resist totalitarianism, inequality, and indifference (Predoiu 2014) 


\section{Herta Müller's liminal figures as a comment on European border regimes}

Herta Müller was born into a pluri-lingual region of Romania in 1953, in Nitzkydorf, a small village inhabited mainly by Banat-Swabian Germans (who migrated eastwards in the $18^{\text {th }}$ and $19^{\text {th }}$ centuries), but also by some Romanians, Hungarians, and Romani, and other, more or less segregated, groups of people. From the very beginning, she fought against censorship by writing against totalitarianism, on one hand, and against the imaginary cultural, social and religious delimitations between groups of people (Lyn, Haines 2013), one the other. Out of her own life-experience in a region that overlapped the borders between Romania, Hungary and Serbia, in a village inhabited mainly by Germans (Glajar 2004) who considered themselves as an uncontested spiritual elite (although being blunt peasants with a Nazi past), Müller aligns her writings against her own family and the German collective. Her first book, Niederungen, already sought to reveal the analogies between the totalitarian state and the logics of ethnic and cultural segregation. German Banat-Swabian nationalism corresponds to totalitarianism; both ideologies attempt to classify people in order to erect mental borders between hierarchized groups and to exclude 'others', as Müller's text unveils. Germans, understanding themselves as a minority and elite, relate in her texts to Romani People, Hungarians, and sometimes even Romanians in just the same way as militant socialists did to 'traitors' and dissidents in Ceauşescu's state. This quite provocative parallel pervades Müllers writings (Patrut 2019), and led to her prosecution by the Romanian Secret Service Securitate, who confiscated and accurately annotated her manuscripts, and also to her symbolic expulsion from the Banat Swabians and their associations- even after her flight to Germany, where she has lived and written since 1987. Müllers work includes three volumes of stories, out of which two have been published under the conditions of censorship in socialist Romania: “Niederungen. Prosa” (1982) [„Nadirs"] and "Drückender Tango" (1984) [“Opressive Tango"]. The novels „Der Mensch ist ein großer Fasan auf der Welt" (1986) [„The Passport"] and "Reisende auf einem Bein" (1989) ["Travelling on One Leg"], together with several stories and essays, are testimonies to her flight and migration to the Federal Republic of Germany. In Germany, Herta Müller soon became well-known with novels such as "Der Fuchs war damals schon der Jäger" (1992) ["The Fox was Ever the Hunter"], essay volumes such as "Der Teufel sitzt im Spiegel" (1991) [The Devil sits in the Mirror"] or "Der König verneigt sich und tötet" (2003) ["The King Bows and Kills"] and her highly innovative collage volumes like "Die blassen Herren mit den Mokkatassen" (2005) ["The Pale Gentlemen with their Espresso Cups". Herta Müller was conferred the Nobel Prize for her entire work after publishing the novel "Atemschaukel" (2008) ["The Hunger Angel"] (Eke 2017), which deals with a taboo issue: the deportation of about 75.000 Germans from Romania to working camps in the Soviet Union in January 1945. One of the deportees was the German-Romanian avantgarde writer Oskar Pastior, who survived the working camps in the Donbas and collaborated with Müller during the conception phase of "Atemschaukel".

Müller's depiction of Romani is one less-investigated aspect of her work. She dedicates the documentary essay "Der Staub ist blind, die Sonne ist ein Krüppel. Zur Situation der Zigeuner in Rumänien" (Müller 1995) to the deprivations faced by the Romani in Romania, pointing out that they still owe an observer position, their looking back being feared despite the stigmatization they face. She portrays Romani as excluded persons who are present in the society that defines itself through their exclusion; this paradoxical status of belonging and not-belonging discloses both their vulnerability and their special observer position looking back at society from its boundaries. Both in the view of Banat-Swabian Germans and of the totalitarian socialist state, Romani hold this ambivalent position-one that makes them vulnerable to insults and discrimination, including physical violence. 
In Müllers writings, as this paper aims to point out, this double liminality makes the Romani destined to become touchstones for resistance against totalitarianism and German nationalism.

Giorgio Agamben, whose consent with Carl Schmitt's concept of the sovereign and the state of exception gave rise to a controversial debate (Norris 2005, de la Durantaye 2009 a.o.), convincingly speaks of liminal figures as those who are hovering between life and death, between the structure of human society and its outside As he has shown in "Homo sacer: Sovereign Power and Bare Life", the type of relationship between the sovereign and those who are excluded from society discloses the assembly of power and thus the structure of society; according to Agamben (Agamben 1998), the rules that make people 'killable' at the same time guarantee order, safety and societal regulation, since they ensure the exercise of power (Ek 2006). This also implies that figures who straddle the realms of order and the outside own the possibility of challenging the order, in this case totalitarianism. The excluded side of liminal figures ceases, paradoxically, to be subordinated to the governance, whose assertiveness at the same time depends on its capacity to impose exclusion and, in extremis, to impose on some groups the status of 'being killable'. For centuries, from about 1600 until World War II, this was status held by 'Gypsies', who were frequently banned from one principality to the next in German territories, prosecuted in the Austrian Empire, and sold as slaves in the Romanian Princedoms (Achim 1998) until the 1850s. National Socialists stigmatized many Romanies as 'anti-social' (Ayass 1995); during the Holocaust, more than half a million people who were referred to as 'Gypsies' were murdered.

In Herta Müller's story "Die große schwarze Achse" ("The Great Black Axis"), published in $1984 / 1987$, a little girl is confronted with the existential experience of death and violence without receiving any explanation that could help her to develop any plausible categories for these phenomena or at least a coherent understanding of the social processes in which she is involved. In other words, the margins between life and death seem highly uncertain, and little by little the readers have to acknowledge that many other borders -between the German minority and Romanian majority, the National Socialist past and Communist present day, the Germans and Romanians on the one hand and the 'Gypsies' on the other, the living and the dead-are no less precarious and threatening: and throughout all these binarism the hidden, most frightening opposition between the state and the people. In essence, this story contains many essential components of modern day narrations on Europe, and especially the conflict between diversity, multilingualism and heterogeneity on one hand and dividing, hierarchizing practices and discourses one the other. This tension, which is always determined by the way it unfolds in narratives, particularly characterizes the concepts of 'Europe' that emerged during the $20^{\text {th }}$ century. The story tries to elaborate on this problem by reference to an exemplary case that emphasizes the aforementioned conflicts.

Like most of Müller's stories, "The Great Black Axis" (Müller 1984) also deals with the oppressive state as a total institution. The protagonist of the story, the young girl, repeatedly imagines an eye that watches her in a threatening way, like the water surface of a deep well which is another metaphor for the omnipresent eye of the state; at the same time, the smooth surface of the water in the deep well promises reflexion and self-understanding. The bias of the subject flashes before the readers, who develop an understanding of the individual's diremption in a totalitarian society as they try to disentangle the internalized perspective of the surveillance state from their own inner voices.

Behind the 'water eye' the girl imagines the big black axis, a machinery of death, rotating like a mill pushed by the already deceased. Thus, the girl's imagination succeeds in reflecting everyday totalitarian violence after all; it creates an adequate image with aesthetic and 
analytical pertinence. Paola Bozzi (Bozzi 2005) has shown that for the narrator, inner and outer world as well as real experience and imagination converge.

According to Goffman, "[a] total institution may be defined as a place of residence and work where a large number of like-situated individuals, cut off from the wider society for an appreciable period of time, together lead an enclosed, formally administered round of life." (Goffman 1961, 11). The eye of death is a metaphor that also refers to the two forms of totalitarianism which Hannah Ahrendt noted as having emerged during the $20^{\text {th }}$ century; this eye has fitted itself over the perception of the inhabitants of the Swabian village; the gaze of the omnipresent eye seems to converge with most character's perception of life. There are but two exceptions: The little girl who is telling the story and the 'Gypsies' who come to the village. Both unsettle the superficial peace of the village - it remains to be shown in what way they irritate it.

Karin Bauer has argued that the novel deals with prohibited reflection and self-reflection (Bauer 1996); this is why the villagers are afraid to look in the 'water eye' of the well. I would like to point out that reflection and developing an awareness for history are quite telling for the 'Gypsy' characters in the story. This narrative structure contains the risk of instrumentalizing the prosecuted group as 'reflector' (Hille 2005); however, it stresses the chances of liminal perspectives and raises questions about conditions and possibilities of 'subaltern speech' in art (Kugler 2004).

At the beginning of the narration, everything seems to be located under the regime of a terrifying gaze, which evaluates all objects and people through the prism of power structures, and this way of viewing simultaneously emanates from and focuses on the inhabitants of the village them.

From the direct surroundings - from the well, the pond, the moon, the smith's empty eye socket or from the arched foot of one dying - looks emanate, speaking of annihilation. Nature and the fellow villagers have become death threats. Müller has employed a narrative technique here, described most emphatically in "Wie Erfundenes sich im Rückblick wahrnimmt" ("How perception invents itself in retrospect") (Müller 1991), in which she points out interdependencies between society and self in totalitarian states, so that external things seem to be part of the self and the self seems to be a part of external things, which are inevitably contaminated and corrupted by totalitarian control.

\section{Liminal Views - Totalitarian Gaze}

This scenario will be described in more detail in the following section, before I analyze the functions of liminality and, finally, offer one specific example of a liminal perspective: the portrayal of the 'Gypsy' in Herta Müller's work. Müller was awarded the Nobel prize for depicting the threatening de-individualization in totalitarian systems; however, the important achievements of her work in this respect are the 'outside views' (Bozzi 2005) described, which unveil hidden structural violence. This applies to the proto- as well as the post-fascist Banat Swabian village and also to the socialist 'big brother'-state, including the Soviet labor camp (Predoiu 2004, 43). Both nullify the individual. Nevertheless, the voice of the individual is articulated in many of Müller's writings as an overtone that disrupts the totalitarian unison. And by means of the aforementioned narrative process, this totalitarian enforcement of conformity is unmasked in its violence. The 'outside view' accompanies the all-homogenizing scrutiny of totalitarianism. This outside, or rather 'liminal' view (Müller 1999) does not see the opposite of the totalitarian gaze; it is a perception that is wounded and scarred by the awareness of the totalitarian view, rather than that of an individual who always partakes of the same totalitarian perspective and thus constantly thinks about how he or she is monitored and standardized by this view through the medium of all objects and people. The 'liminal view' is located on the edge of the totalitarian regime; it stands more or less with one leg inside and with the other outside; it is subject 
to the spell of totalitarianism, but, at the same time, it looks back to its structures of repression and reflects upon them. Hence, it occupies the space where Agamben positioned his liminal figure, the 'homo sacer'.

Here I do not wish to refer to Agamben's controversial conception of the concentration camps, but rather to indicate correspondences or parallels between Agamben's idea of the 'liminal figure' (other than liminality during fascism) and the societal places where Müller locates some of her protagonists. They, too, find themselves in a borderland or in-between region from where power defines and at the same time limits itself, there where it must prove its sovereignty (Agamben 1998), but where, at the same time, the possibility of subversion occurs. First, Müller describes the impotence of those who are at the mercy of the arbitrary power of the totalitarian state, which can punish or pardon at will, and develops a critical potential, even if the characters themselves often experience a mostly hopeless existence at the mercy of the state. This also applies, for example, to Windisch and Amalie in the story "Der Mensch ist ein großer Fasan auf der Welt" (Müller 1996), just as it does to the protagonists in the novel "Herztier" (Müller 1994)-the poor girl Lola and the Banat Swabians Edgar, Kurt and Georg, who remind the reader of the literary group 'Aktionsgruppe Banat'. Here the protagonists look at the world from the edge of the system - and from perspectives near the political borders, which they are keen to trespass.

In Müller's works we also find figures with special needs, like Planton-Kati in the novel "Atemschaukel" (Müller 2009). This character is imprisoned in the same Russian labour camp as the main protagonist Leopold Auberg. She is the liminal figure who is marginalized by the already excluded; she is outcast of the outcasts. At the same time, it is uncertain whether she succumbs to the de-subjectifying grasp of the camp; because of her different personality structure, she does not need to defend herself against the annihilation of her individuality, at least not according to the narration. To a certain extent, the conditions in the camp are reversed in her case, because other prisoners help her and do not wish to compete with her for food. Because the all-controlling and monitoring camp authorities are stymied by her lack of understanding and her indifference, she develops what is probably an unconscious subversive potential. Through her failure to appear at roll call, or her behavior in remaining seated despite the 'Attention!' order, for example, the unlimited power of the total institution paradoxically crumbles. Something similar occurs when she receives the otherwise destroyed solidarity of those who are imprisoned: when the opportunity arises, they give her food rather than taking it away from her. It is not a coincidence that Planton-Kati survives the labor camp; her survival is related to her extreme liminality and the correlative possibilities of resisting governance.

In this way, Müller depicts different types of liminal personality and narrates the traumatic history of Europe from the perspective of liminal figures, whose voices carry traces of the injuries caused by the violence of European border regimes such as the 'Iron Curtain'.

\section{4. 'Gypsy' Characters in "The Big Black Axis"}

In the story "The big black axis", first published in "Barfüßiger Februar" in 1986, the narrator's voice tracks a child who is part of a Banat Swabian family. At first glance, they lead a well-organized life, and the parents seem to be convinced that their habits entitle them to feel superior vis-à-vis the Romani. Gradually, readers come to know that a Nazi past and German songs from World War I are part of this cultural legacy. The child is sent by his mother to fix a broken chain - an ambivalent symbol of resistance, and of interruption of the intergenerational chain, as it could link the world of the living with that of the underground and the dead ancestors who, the child imagines, are turning the big black axis of time. The child does not stop by the smith's house. Instead, the child, probably a girl, attends a 'Gypsy' performance in a field nearby the village, where many characters meet 
even though everybody claims to despise Romani, who are considered as total outsiders. The Romani play manages to reverse and to reflect upon the observation regime, revealing the double standards of the spectators, who in truth own all the defects they project upon 'Gypsies', thus giving the Romani the power of interpretation over the society that excludes them. After the play, the child goes back home and is punished by his mother. The child is the first-person-narrator, but at the same time - as in the anterior volume "Niederungen" (Kegelmann 2014) -the story contains much more than the child's perspective. For instance, the child in "The Big Black Axis" doesn't fully understand the implications of war songs sung by the adult. The child suddenly starts to variegate violent scenes from fairy tales, which interact with the main plot, without being aware of itin addition, the childprobably does not understand the entire meaning of the 'Gypsy' performance of the play "Genieve". This mirrors the state of mind of the Banat-Swabian group. Without getting the entire context, the child senses that the 'Gypsy' group unveils and subverts the violence of the majority, just like the child itself when opposing parental authoritarianism and force. Thus, the readers are given the possibility of subversion and resistance by alliance with the Romani (Hofmann/Patrut 2015, 93).

The 'Gypsy' characters in Müller's "The Great Black Axis" are 'liminal figures' in a very radical way. Unlike characters like the narrator or Planton-Kati in "Atemschaukel", the "Gypsies' that come to the village fully understand the structures of inner and outer borders and the rules of power; and because they are artists and perform a theatre play, they have the power to launch own interpretations of society and to bring in their own voices and perspectives. This is not at all uncommon for 'Gypsies' in German literature. In "Die fünf elenden Wanderer" (1539), Hans Sachs portrays an extremely poor but honest 'Gypsy', who reveals social realities as well as the true character of other protagonists by telling their fortune. This motif is quite widespread, occurring not only in plays by Hans Sachs such as "Die Rockenstuben" (1536), but also in baroque literature such as Grimmelshausen's "Lebensbeschreibung der Ertzbetrügerin und Landströtzerin Courasche" (1669) and in dramas of the Sturm und Drang, such as Goethe's "Götz von Berlichingen" (1773), where 'Gypsies' who live in the woods seem to be the only ones - besides Götz - who understand the mistakes and double standards of society (although their belonging to it is limited); this is why they support Götz. In the texts of German realism, such as Gottfried Keller's "Romeo und Julia auf dem Dorfe" (1855/56), a fiddler who is - falsely - presumed to be a 'Gypsy' is the only one who understands the violence and hypocrisy of bourgeois society. Being himself hit by the mechanisms of exclusion, he reflects on them and discloses them to the reader. 'Gypsy' figures were often given the role of reflectors of European history, its transformations, and its inner and outer borders.

Müller's text assumes the motif of the 'Gypsies' who know and tell the truth about all kinds of borders, and who divulge the hidden aggressive side of power and society, adapting it to the Banat Swabian society during socialist regime.

In the aforementioned story "The Great Black Axis," Gypsies primarily seem to be nonintegrated intruders. Before their arrival, the readers get to know the girl, the grandfather, mother and father, additional relatives, the neighbour Leni with her broken family, and other village residents who have a different ethnic belonging. Via the metaphor of the eye, the omnipresence of death appears in the scenes of everyday life. Thus, the father eats an 'eye of fat in the soup' (Müller 1984, 7), and the mother cannot see (or rather has no eyes for) the 'dead ant' in the soup (Müller 1984, 7). During a visit with a seriously ill neighbour, the young first-person narrator believes she sees the well in the eyes of the dying neighbor- a well whose depths she suspects of holding the 'black axis' (Müller 1984, 6) of time and death. 
The text describes everyday scenes from the lives of the German minority in Romania, whose members have obviously not yet critically examined their Nazi past. On holidays such as Easter Sunday, when the grandfather meets with other Germans who were once his comrades-in-arms, he speaks of having been "a prisoner of war," of "the military cemetery for heroes" or "Mostar" (Müller 1984,13). Admittedly, he is speaking about World War I; nevertheless, it is noticeable that his fragmentary memories are pervaded by German war propaganda jargon.

So-called mixed marriages with members of other ethnic groups are frowned on as illegitimate border-crossings. The young neighbour, Leni, who is having an affair with a Romanian tractor driver named lonel and is pregnant with his illegitimate son, is accused by the villagers of driving her old father to his grave because of the supposed disgrace; and he does actually die: "A Wallach is a Wallach, there's nothing else to be said" (12), the narrator's uncle says about lonel. The story stresses unnecessary borders erected by the inhabitants of the village; the distinctions they draw and the social barriers they erect seem to reproduce the big border separating Eastern from Western Europe. In the small world of a pluricultural, multilingual European village, the large European frontiers re-enter the minds and the societal practices of Europeans again and again, until they are caught into a dense network of imaginary margins and self-erected borders which paralyses them.

Nothing indicates that the bad attitudes of the 'Wallach' apply any less to the members of the German minority. Roxane Compagne has pointed out that Leni despises a young 'Gypsy' woman in a racist way - although she herself is being called a deviant (Compagne 2010). Stereotypes are refuted.

Only at first sight do 'Gypsies' seem to be of secondary importance. Stefan Gross has shown that they possess a crucial role in the story because they represent radical exclusion, the metaphor of homelessness (as Egyptian pilgrims) and the confrontation with death (Gross 1991). Indeed, the girl goes to the 'Gypsy' performance carrying a chain, as if she intended to throw it into the well and extract the forbidden reflection. Besides, the portrayal of the 'Gypsies' in "The Great Black Axis" follows a contrapunctal structure. As soon as they know that 'Gypsies' have come into the village, the inhabitants start blaming them of theft, promiscuity and fraud. Nevertheless, most of them join the performance of the 'Gypsies' - a staging of the legend on Geneve (Staritz 2005). Thus, the 'Gypsies' perform a play that deals with an liminal figure - Geneve - and with the right to kill her, thereby exposing the history of social exclusion and assuming the role of subjects of the story. Geneve only survives because a bleeding heart of a deer is alleged to be hers, as a reflection upon the precarity of liminal figures, whose life has a status similar to that of non-human being: both are 'killable'. At the same time, the play deals with prohibited sexual desire. In the end, it turns out that not Geneve tried to seduce the vice-regent; it was the vice-regent who had been rejected by the king's wife, and who subsequently he accused her of adultery, as he was seeking revenge.

In the legend, Geneve is the outlawed scapegoat. Thus, the deviance attributed to her is located in the very center of power, the same center that (re)establishes its legitimacy by excluding her. Geneve survives and lives as a liminal figure in the woods - a position that has certain similarities with 'Gypsy' motives. Müller's 'Gypsies' deliberately appropriate this liminal situation in the discourse by performing a play on the outlawed wife and by making the villagers aware of the rules of the exclusion of 'Gypsies'. At the same time, the social order is re-established in the legend as well as in the intrinsic logic of the play by means of Geneve's rehabilitation. But in the social reality, there is no rehabilitation of the excluded -there is just increased awareness of it brought on by the performance. 'Gypsy' actors interrogate both this order of things and the regime of sexuality by including an interplay dealing with 'Gypsy' musicians and actors as amusement for the non-'Gypsies', and by choosing an actress that doesn't embody Geneve's chastity. This also applies to the 
young 'Gypsy' dancer in a transparent robe who collects the money at the end of the play. Her appearance and performance mirror the desires of the villagers, while the bleeding heart of Geneve/the deer correlates with the violence of the political regime and the little girl's apperception of death and 'being killable', condensed in the metaphoric image of the 'big black axis'. The members of the Banat German minority themselves show most of the negative attributes that they ascribe to the 'Gypsies'. Banat Swabians are more likely to exhibit dishonesty and fraud than do the 'Gypsies', who a neighbour accuses of having stolen her chicken - which, as it turns out, had already disappeared a day before the 'Gypsies' arrived.

Olivia Spiridon has drawn the attention to the tale of Snow White that the narrator is reading and adapting as a passe-partout for experienced hate and violence (Spiridon 2002). In my reading, the text shows that it is not sufficient to look at the social structures through the prism of this fairy tale, as the narrator does. In a way, the narrator looks at the world simplistically, as if it was a tale with fixed 'good' and 'bad' characters and positions. The child, probably a little girl, imagines herself as 'Snow White', an innocent victim, and opens up a possibility of an 'innocent' Banat Swabian position, as the Swabians also saw themselves as victims of the historical processes, being caught within the Eastern Block. This would correlate with the motive of the omniscient 'Gypsy' who holds the key to the 'real' (innocent) German identity, as Goethe's "Götz" puts it. But the reliability of this construction is called into question by the untrustworthy perspective of all of the figures in the text except for the 'Gypsies'. Even the narrator's voice is that of a young girl who still believes in fairy tales. She imagines that the attempt to kill would symbolize the attempt to kill Snow White-that is, herself. But this view is unveiled as wrong; the play refers to European history and its great demarcations, its rules of sovereignty, its outlaws and scapegoats, who are in the worst case 'killable' because they were outlawed.

\section{Outlook}

'Gypsies' look back at the totalitarian gaze and at the European border regime in Herta Müller's story. In "Der Teufel sitzt im Spiegel" [The Devil sits in the mirror], Herta Müller argued that every mirroring gives the opportunity to see something else, to subvert violent gazes of the authoritarian state and to regain subjective autonomy. In some sense, the 'Gypsy' theatre is an example for such a subversive mirroring.

On the whole, with the 'Gypsies' Herta Müller has created liminal figures who touch the painful truth of totalitarianism in Romanian socialist society. They make possible reflection on social structures as well as self-reflection, and reflect on their own exclusion and attenuate it by collecting money for their performance. In "Die große schwarze Achse" and "Der Staub ist blind - Die Sonne ist ein Krüppel. Zur Situation der Zigeuner in Rumänien" ("Dust is Blind - The Sun is a Cripple. On the Situation of the 'Gypsies' in Romania"), we find reflections on the entanglements of inner and outer border regimes and on totalitarian indifference toward the individual (Overath 2004). The 'Gypsies' appear as a resistant group, subverting the totalitarian standardization of all areas of life, but they do not reaffirm the stereotype of the Bohemian. Thus, Herta Müller manages to criticise not only the socialist state and its inner and outer border politics, but also the European border regime. Her texts commemorate that 'Gypsies' were presumed to be 'Asians', 'Indians' or 'Orientals', and seen as belonging outside the outer European borders. At the same time, the evidence that they belonged to Europe was so strong, that they were caught in the role of liminal figures.

Today, the greatest part of the Romani minority lives in Eastern Europe; worldwide there are over 10 million Sinti and Romani. It is especially to Herta Müller's credit that she addressed the precarious living conditions of the Romani and their day-to-day experiences of exclusion as early as the 1980s, at a time when the political organization of the Romani 
was still in its initial stages, in Western Europe as elsewhere. The 'Gypsy' figures in Herta Müller's works constantly live on the edge of poverty and are much more severely threatened by squalor, misery, and illness than the rest of the population. They must improvise to survive. This is a strongly realistic-analytical characteristic of all of Müller's works, and it guarantees that she will do the portrayed minority justice. With the play on Geneve, Roma characters look back not only at totalitarianism, but also at the regime of exclusion to which they have been subjected since their $13^{\text {th }}$-century arrival in the Romanian Princedoms, where they are considered 'oriental' strangers and non-Europeans.

By offering a Romani perspective, therefore, the story points to the highly entangled history of European inner and outer border demarcations, where inner and outer frontiers sustained each other. Art - both Herta Müller's story an the Romani art depicted in it claims to reflect on these blind spots and to reveal how European inner and outer borders are erected and legitimized.

Generally speaking, this example shows how literary texts register with seismographic accuracy the narratives of inclusion/exclusion that underlie widespread societal self-depictions in Europe. The case of the Romani reveals that societies before and after the end of socialist states 1989 in Eastern and Western Europe have shared similar stigmatizations and have constructed liminal figures that are quite similar to each other. Nevertheless, literary texts like the stories, novels and essays by Herta Müller have developed narrative strategies to unveil stigmatizing discourses, such as those against Romani. Thus, the usurpation of persons portrayed by society as liminal figures in order to ensure social bonding among the majority becomes questionable. The most important literary narrative strategy used by Müller is the reversal of the gaze. The scientific, popular, and political discourses that stigmatizes and excludes Romani, relegating them to the threshold of society, is successfully challenged by counter-narratives and stagings initiated by Romani themselves. In addition, unmasking the inconsistency of the 'Gypsy' stigma causes main-stream narrations about the 'self' and 'other' to unravel. German Banat Swabians are, themselves, acting in ways that they project on the Romani. By placing the story in the multilingual, multireligious region of Banat, Müller crates a laboratory of European self-depictions and challenges narratives of belonging. From its setting in a Banat-Swabian village, her story evokes, in a nutshell, the conflicts between multilingualism, heterogeneity and diversity on one hand, and homogeneity, nationalism, and hierarchy on the other - conflicts that have long characterised Europe and are still ongoing. She portrays Romani as second-level observers, who are able to see through dichotomic narratives of inclusion/exclusion. Thus, the strengths of literary narrations do not mainly consist in creating new narratives of Europe (which would, of course, be quite easy), but in reflecting on existing ones and unveiling the blind spots and illegitimate exclusions that create liminal perspectives and countergazes from the threshold of the continent.

\section{References}

Achim, V. (1998). Tiganii în istoria României. Bucharest: Ed. Enciclopedică.

Agamben, G. (1998). Homo Sacer. Sovereign Power and Bare Life. Stanford: Stanford University Press.

Ayass, W. (1995). >Asoziale< im Nationalsozialismus. Stuttgart: Klett-Cotta.

Bauer, K. (1996). Lebensphasen und Existenzweisen: Prostitution, Ehe, Wahnsinn. Freiburger FrauenStudien (2) 1. 21-31. 
Bogdal, K.-M. (2011). Europa erfindet die Zigeuner. Eine Geschichte von Faszination und Verachtung. Frankfurt am Main: Suhrkamp.

Bozzi, P. (2005). Der fremde Blick. Zum Werk Herta Müllers. Würzburg: Königshausen \& Neumann.

Compagne, R. (2010). >Fleischfressendes Leben.< On foreignness and hopelessness in Herta Müller's Barfüßiger Februar. Hamburg: Igel.

Cseika, G.; Sienerth, S. (Eds.) (2015). Vexierspiel Securitate. Rumäniendeutsche Autoren im Visier des kommunistischen Geheimdienstes. Pustet: Regensburg.

de la Durantaye, L. (2009). Giorgio Agamben. A Critical Introduction. Stanford: Stanford University Press.

Ek, R. (2006). Giorgio Agamben and the Spatialities of the Camp: An Introduction. Geografiska Annaler. Series B, Human Geography 88.4, 363-86.

Eke, N. O. (Ed.) (2017). Herta Müller Handbuch. Stuttgart: Metzler.

Glajar, V. (2004). The German Legacy in East-Central Europe. New York: Rochester.

Goffman, E. (1961). Asylums: essays on the social situation of mental patients and other inmates. Garden City, N.Y: Anchor Books

Gross, S. (1991). Dem Schmied ist Glut ins Aug gespritzt. Von realen und erfundenen Teufeln. Zur Erzählung >Die große schwarze Achse<. In N.O. Eke (Ed.), Die erfundene Wahrnehmung. Annäherung an Herta Müller. Paderborn: Igel, 1991, 60-73.

Haines, B; Marven, N. (Eds) (2013). Herta Müller. Oxford: Oxford University Press.

Hille, A. (2005): Identitätskonstruktionen. Die »Zigeunerin « in der deutschsprachigen Literatur des 20. Jahrhunderts. Würzburg: Königshausen\&Neumann.

Hofmann, M; Patrut, I.-K. (2015). Einführung in die interkulturelle Literatur. Darmstadt: WBG.

Hormuth, D. (2013). Border Region and Propaganda. Livonia as a Bulwark of Christianity in the Sixteenth Century. In R. Eßler, S. G. Ellis (Eds.), Frontier and Border Region in Early Modern Europe. Hannover: Wehrhahn. 139-155

Kegelmann, R. (2014). Figurenkonstellationen. In: N.O. Eke (Ed.): Herta Müller Handbuch. Stuttgart: Metzler, 176-184.

Kpao Saré, C. (2015). Das postkoloniale Potential der Literarisierung von Völkerschauen in der deutschsprachigen Literatur. Recherches Germaniques 45, 143-154.

Kugler, S. (2004). Kunst-Zigeuner. Konstruktionen des,Zigeuners' in der deutschen Literatur der ersten Hälfte des 19. Jahrhunderts. Literatur - Imagination - Realität, Vol. 34. Trier: WVT Wissenschaftlicher Verlag. 
Lotman, J. M. (1972). Die Struktur literarischer Texte. München: Fink.

Mecklenburg, N. (2008). Das Mädchen aus der Fremde. Germanistik als interkulturelle Literaturwissenschaft. München: iudicium.

Müller, H. (1986). Der Mensch ist ein großer Fasan auf der Welt. Berlin: Rotbuch.

Müller, H. (1987). Die große schwarze Achse (6-25). In Barfüßiger Februar. Erzählungen. Berlin: Rotbuch.

Müller, H. (1995). Der Staub ist blind - die Sonne ein Krüppel. Zur Situation der Zigeuner in Rumänien. In H. Müller: Hunger und Seide. Essays (136-153). Reinbek: Rowohlt.

Müller, H (2009). Atemschaukel. München: Hanser.

Norris, Andrew (Ed.) (2005). Politics, Metaphysics, and Death: Essays on Giorgio Agamben's "Homo Sacer". Durham and London: Duke University Press.

Overarth, A. (2004). Das halbe Brot der Vögel. Portraits und Passagen. Göttingen: Wallstein.

Patrut, I.-K. (2013). ,Zigeuner' als Grenzfigur deutscher Selbstentwürfe. Geschichte und Gesellschaft. Zeitschrift für Historische Sozialwissenschaft 39/3, 286-305.

Patrut, I.-K. (2014). Phantasma Nation. ,Zigeuner' und Juden als Grenzfiguren des ,Deutschen'. Königshausen \& Neumann: Würzburg.

Petrescu, Cristina (2014). Eine Zeugin gegen die Securitate. Herta Müller versus Akte „Cristina“. In: J. Putkammer, S. Sienerth, U. A. Wien (Eds.): Securitate in Siebenbürgen. Köln: Böhlau, 342-373.

Predoiu, Graziella (2014). "> Gefahr, ins Leere zu stürzen<: Außenseiter und aus der Realität Ver-rückte in den Texten Herta Müllers. In: D. Merchiers, J. Lajarrige, S. Höhne (Eds): Kann Literatur Zeuge sein? Poetologische und politische Aspekte in Herta Müllers Werk. Bern: Peter Lang, 175-193.

Robinson, R. (Ed.) (2007). Narratives of the European Border. A History of Nowhere. Hampshire: Palgrave Macmillan.

Spiridon, O. (2002). Untersuchungen zur rumäniendeutschen Erzählliteratur der Nachkriegszeit. Oldenburg: Igel.

Staritz, S. (2005). Geschlecht, Religion und Nation. Genoveva-Literaturen 1775-1866. St. Ingbert: Röhrig.

Uerlings, H. (2006). „Ich bin von niedriger Rasse“. Postkolonialismus und Geschlechterdifferenz in der deutschen Literatur. Köln: Böhlau. 
